K A N D A I

\begin{tabular}{|l|l|l|}
\hline Volume 16 & No. 2, November 2020 & Halaman 205-216 \\
\hline
\end{tabular}

\title{
KOMPOSITUM IDIOMATIS DALAM BAHASA MANDAR (Idiomatic Compound in Mandarese Language)
}

\author{
Jerniati I. \\ Balai Bahasa Sulawesi Selatan \\ Jalan Sultan Alauddin Km 7, Tala Salapang, Makassar, Indonesia \\ Telepon: 0411-882401, Faksimile: 0411-882403 \\ Pos-el: jerniati.indra@kemdikbud.go.id
}

(Diterima: 10 Januari 2020; Direvisi: 5 Mei 2020; Disetujui: 1 November 2020)

\begin{abstract}
The writing aims at uncovering idiomatic compounds in Mandarese language. It applies structural morphology theory using descriptive qualitative through technique of collecting data such as: observation, taking note, and retrospection. Result of research shows that the construction of idiomatic compound in Mandarese language could be formed based on some patterns, namely (base form+base form), (affixes word+base form), (base form+affixes word), (repetition+base form), and (base form+repetition) patterns. Unique construction is found in (affixes word+base form) pattern, the component of both compounds consists of animal names that become analogy of form, situation and nature of human being. The meaning of compound is solidarity and education but also implies positive and negative meaning. Idiomatic compound of Mandarese language places the function of subject, predicate, object, and adverb in construction of sentence.
\end{abstract}

Keywords: idiomatic compound, Mandarese language

\begin{abstract}
Abstrak
Tulisan ini bertujuan mendeskripsikan kompositum idiomatis bahasa Mandar. Tulisan ini menggunakan teori morfologi struktural dengan metode deskriptif kualitatif dengan teknik pengumpulan data: observasi,pencatatan, dan retrospeksi. Hasil kajian menunjukkan bahwa konstruksi kompositum idiomatis bahasa Mandar dapat dibentuk dari beberapa pola, yaitu pola (kata dasar+kata dasar), (kata berimbuhan+kata dasar), (kata dasar+kata berimbuhan), (kata ulang+kata dasar), dan (kata dasar+kata ulang). Konstruksi unik ditemukan pada pola (kata berimbuhan+kata dasar), komponen kedua kompositum ini semuanya diisi oleh nama binatang yang menjadi analogi bagi bentuk, keadaan, dan sifat manusia. Muatan makna kompositum adalah solidaritas dan pendidikan di samping muatan yang bersifat positif dan negatif. Kompositum idiomatis bahasa Mandar dapat menduduki fungsi subjek, predikat, objek, dan keterangan dalam konstruksi kalimat.
\end{abstract}

Kata-kata kunci: kompositum idiomatis, bahasa Mandar

DOI: $10.26499 / j k . v 16 i 2.2024$

How to cite: Jerniati I. (2020). Kompositum idiomatis dalam bahasa Mandar. Kandai, 16(2), 205-216 (DOI: $10.26499 / j k . v 16 i 2.2024)$

\section{PENDAHULUAN}

Keberadaan bahasa-bahasa daerah merupakan kekayaan budaya yang tidak ternilai harganya. Hal tersebut tidak dapat dimungkiri, karena keragaman bahasa itu sejak lama telah tersebar di seluruh nusantara. Informasi peta bahasa di Indonesia, khususnya di Sulawesi terdapat kurang lebih 54 bahasa daerah (Sugono, 2008). Hal ini menjadi salah satu warisan yang paling berharga bagi 
bangsa Indonesia. Jadi, wajar jika ditempuh berbagai upaya untuk meneliti dan menampilkan bahasa-bahasa itu serta berusaha memelihara dan mengembangkannya.

Bahasa-bahasa di Sulawesi dibagi menjadi beberapa kelompok, satu di antara kelompok tersebut adalah keluarga bahasa-bahasa Sulawesi Selatan bagian utara (sekarang Sulawesi Barat), termasuk di dalamnya bahasa Mandar (Grimes, 1987). Bahasa Mandar adalah salah satu bahasa daerah yang dituturkan oleh etnis Mandar yang berada di wilayah Provinsi Sulawesi Barat. Bahasa Mandar terdiri atas beberapa dialek yaitu, 1) dialek Balanipa, 2) dialek Majene, 3) dialek Pamboang, 4) dialek Sendana, 5) dialek Awoq Sumakuyu, dan 6) dialek Malunda (Indra, 2019a).

Tulisan ini menggunakan dialek Majene sebagai objek kajian. Dialek ini dipilih dengan pertimbangan bahwa dialek ini digunakan oleh masyarakat yang berdiam di Kabupaten Majene dan dianggap representatif sebagai daerah sampel karena bahasa Mandar yang digunakan di tempat itu adalah bahasa Mandar yang tidak banyak mendapat pengaruh dari luar.

Penelitian bahasa Mandar yang setema dengan tulisan ini adalah "Sistem Pemajemukan Bahasa Mandar" Indra, 2003) dan "Penanda Kompositum Bahasa Mandar" (Jerniati I., 2019b). Penelitian yang pertama membahas bentuk-bentuk kata majemuk bahasa Mandar termasuk kata majemuk dasar, kata majemuk berimbuhan, dan kata majemuk berulang. Selain itu, juga diulas mengenai makna nomina majemuk, verba majemuk, numeralia majemuk, dan adjektiva majemuk. Adapun tulisan kedua, membahas penanda kompositum bahasa Mandar yang berdasar pada penanda aspek fonologis (penambahan dan asimilasi), aspek morfologis (bentuk dasar dan turunan), dan aspek sintaksis (unsurunsur kata majemuk tidak dapat disisipi, diganti, atau ditukar dengan kata lain).

Kedua penelitian/tulisan tersebut mengulas kompositum atau kata majemuk bahasa Mandar secara umum, belum membahas aspek-aspeknya secara detail. Jadi, penulis secara khusus mengangkat kompositum idiomatis dalam bahasa Mandar. Kompositum idiomatis ini menarik karena aspek morfologi berkolaborasi dengan aspek makna. Di samping itu, kompositum ini juga unik karena mengambil nama binatang menjadi salah satu komponen pembentuknya.

Kompositum idiomatis adalah kompositum yang maknanya tidak sama dengan makna komponen-komponen yang membangunnya. Makna khusus yang timbul dalam satu kompositum idiomatis dapat memuat berbagai nilai dalam kehidupan keseharian masyarakat Mandar. Penggunaan makna khusus tersebut dalam gaya bahasa disebut metafora. Idiom yang mengandung kompositum semantik metaforis merupakan bagian dari subidiomatik dari idiom sintaksis (Dabrowska, 2018).

Tulisan ini bertujuan melanjutkan dan melengkapi penelitian bidang morfologi bahasa Mandar. Berdasarkan pada uraian sebelumnya, rumusan khusus yang akan dibahas dalam tulisan ini adalah konstruksi kompositum idiomatis dalam bahasa Mandar dan muatan makna yang termuat dalam kompositum idiomatis bahasa tersebut.

\section{LANDASAN TEORI}

Landasan teori sebagai landasan kerja yang digunakan dalam tulisan ini adalah teori linguistik structural, yaitu teori memandang bahasa itu sebagai unit-unit yang tersusun dalam suatu struktur sehingga bahasa mempunyai strukturnya sendiri dan khas 
(Bloomfield, 1933). Linguistik struktural merupakan pendekatan dalam penyelidikan bahasa yang menganggap bahasa sebagai sistem yang bebas. Dalam penentuan kategori kata, linguistik struktural sangat berpegang pada struktur atau posisi sebuah kata dalam suatu konstruksi (Kridalaksana, 2008).

Konstruksi kompositum sebagai fokus tulisan ini merujuk teori yang menyatakan bahwa kata majemuk adalah gabungan morfem dasar yang seluruhnya berstatus sebagai kata yang mempunyai pola fonologis, gramatikal, dan semantis yang khusus - menurut kaidah bahasa yang bersangkutan (KBBI V edisi luring). Selanjutnya, dikatakan pula bahwa kata majemuk adalah proses penggabungan dua leksem atau lebih yang komponen-komponennya masingmasing tidak dapat dimodifikasi (Kridalaksana, 2013: 111-112).

Kompositum juga memiliki pengertian gabungan dua kata atau lebih yang memiliki struktur tetap, tidak dapat disisipi kata lain atau dipisahkan strukturnya, karena akan memengaruhi arti secara keseluruhan. Istilah lain untuk kata majemuk adalah komposisi. Komposisi adalah proses penggabungan dasar dengan dasar (biasanya berupa akar maupun bentuk berimbuhan) untuk mewadahi suatu "konsep" yang belum tertampung dalam satu kata (Chaer, 2008). Bertolak pada pendapat para pakar tersebut, dalam makalah ini penulis cenderung menggunakan kata kompositum sebagai satu istilah yang menggabungkan dua komponen untuk menciptakan suatu konsep yang baru.

\section{Ciri-Ciri yang Membedakan Kompo- situm dari Frasa}

Ketaktersisipan; yaitu komponenkomponen kompositum tersebut tidak dapat disisipi apa pun. Bilamana komponen tersebut dapat disisipi oleh bentuk lain, baik itu morfem, kata atau apa pun, itu berarti bahwa kata tersebut dipastikan bukan kata majemuk atau kompositum.

Ketakterluasan; yaitu komponenkomponen kompositum tersebut tidak dapat diafiksasi dan dimodifikasi. Jika terjadi perluasan, itu pun hanya mungkin untuk semua komponen sekaligus. Dalam bahasa Mandar, kata lipaq saqbe apabila diperluas menjadi lipaq saqbe Mandar.

Ketakterbalikan; yaitu komponenkomponen tersebut tidak dapat ditukar. Dalam bahasa Mandar, kata mandoeq tedong adalah kompositum karena kalau dibalik menjadi tedong mandoeq 'kerbau mandi' posisinya bukan lagi kompositum, melainkan struktur yang lebih besar, yaitu sintaksis.

Kompositum juga dapat dibagi berdasarkan tema makna, yaitu 1) kompositum nonidiomatis (kompositum yang maknanya sama dengan makna komponen-komponennya); kompositum semiidiomatis (kompositum yang salah satu komponennya mengandung makna khas); dan 3) kompositum idiomatis (kompositum yang maknanya tidak sama dengan makna komponen-komponennya). Sejalan dengan hal itu, thematic composition adalah sebuah ungkapan yang mempunyai komposisi tematik, apabila struktur tematik verba berada pada makna literalnya, maka verba dengan makna idiomatik terlihat mirip (Dabrowska, 2018).

Tulisan ini mengikuti konsep dan prinsip yang berlaku dalam kerangka teori linguistik deskriptif yang disesuaikan dengan korpus data yang terkumpul. Kompositum idiomatissebagai fokus tulisan ini-merupakan gabungan kata yang makna keseluruhannya tidak dapat dijabarkan dari makna komponennya masing- 
masing. Dalam KBBI V (edisi luring), idiom didefinisikan sebagai konstruksi yang maknanya tidak sama dengan gabungan makna unsurnya.

\section{METODE PENELITIAN}

Penulis menggunakan dua macam metode pengumpulan data, yaitu metode lapangan dan metode pustaka. Metode lapangan digunakan untuk memperoleh data primer, sedangkan metode pustaka digunakan sebagai penunjang data primer. Selanjutnya, teknik yang dipakai untuk mengumpulkan data adalah 1) teknik observasi digunakan untuk mengamati berbagai bentuk afiks dan morfem yang berperan dalam konstruksi kompositum idiomatis bahasa Mandar, 2) teknik wawancara dilakukan untuk mendapat tuturan langsung dari informan dibantu dengan instrumen berupa daftar pertanyaan dua ratus kata dasar beserta turunannya dan penggabungannya, 3) teknik pencatatan dilakukan untuk mencatat data yang berkaitan dengan konstruksi kompositum idiomatis bahasa Mandar, dan 4) teknik retrospeksi digunakan untuk menyeleksi semua data yang diperoleh untuk mendapatkan data yang akurat.

Sumber data primer penelitian berasal dari tuturan informan, sedangkan data sekunder bersumber dari hasil penelitian sebelumnya, baik yang sudah diterbitkan dalam bentuk buku, jurnal, majalah maupun yang belum diterbitkan, misalnya naskah-naskah hasil penelitian. Untuk memperoleh data yang akurat, dipilih informan yang berasal dari penutur jati bahasa Mandar dialek Majene sebanyak dua puluh orang.
Informan tersebut dipilih dan ditetapkan berdasarkan syarat-syarat pemilihan dengan kriteria sebagai berikut.

1) Informan berjenis kelamin pria atau wanita.

2) Informan berusia 25-65 tahun (tidak pikun).

3) Orang tua, istri, atau suami responden lahir dan dibesarkan di desa itu serta jarang atau tidak pernah meninggalkan desanya.

4) Informan berpendidikan maksimal tamat pendidikan dasar (SDSLTP).

5) Informan berstatus sosial menengah (tidak rendah atau tinggi) dengan harapan tidak terlalu tinggi mobilitasnya.

6) Informan memiliki kebanggaan terhadap isolek dan masyarakat isoleknya.

7) Informan dapat berbahasa Indonesia, dan sehat jasmani dan rohani (Mahsun, 2005).

Informan dapat berbahasa Indonesia, dan sehat jasmani dan rohani (Mahsun, 2005).

\section{PEMBAHASAN}

\section{Pola Kompositum Idiomatis Bahasa Mandar}

Konstruksi kompositum idiomatis bahasa Mandar dapat dibentuk dari beberapa pola, yaitu pola (kata dasar+kata dasar), (kata berimbuhan+kata dasar), (kata dasar+kata berimbuhan), (kata ulang+kata dasar), dan (kata dasar+kata ulang). Diuraikan sebagai berikut.

Tabel (1)

Kata Dasar+Kata Dasar

\begin{tabular}{c|c|c|c}
\hline No & Kata Dasar & Kata Dasar & \multicolumn{1}{c}{ Kompositum } \\
\hline 1. & Baliq [bali?] 'balig' & Manuq [manu?]'ayam' & $\begin{array}{l}\text { Baliq manuq [bali? manu?] } \\
\text { 'balig seperti ayam' }\end{array}$ \\
\hline
\end{tabular}




\begin{tabular}{|c|c|c|c|}
\hline 2. & $\begin{array}{l}\text { Mottong [mot:oๆ] } \\
\text { 'tinggal/bermalam' }\end{array}$ & Manuq[manu?] 'ayam' & $\begin{array}{l}\text { Mottongmanuq [mot:oך manu?] 'tamu } \\
\text { yang bermalam tanpa disuguhi makan } \\
\text { malam' }\end{array}$ \\
\hline 3. & 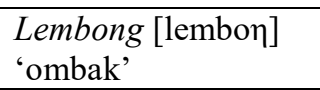 & Tallu [tal:u] 'tiga' & $\begin{array}{l}\text { Lembong tallu [lembon tal:u] 'gelombang } \\
\text { yang besar' }\end{array}$ \\
\hline 4. & $\begin{array}{l}\text { Kayyang [kay:aך] } \\
\text { 'besar' }\end{array}$ & $P a u[\mathrm{pau}]$ 'bicara' & $\begin{array}{l}\text { Kayyang pau [kay:a p pau] 'besar } \\
\text { bicara/sombong' }\end{array}$ \\
\hline 5. & Lappiq[lap:i?] 'lipat' & Daqdua [daPdua] 'dua' & $\begin{array}{l}\text { Lappiq daqdua [lap:i? da?dua] } \\
\text { 'keuntungan ganda' }\end{array}$ \\
\hline 6. & $\begin{array}{l}\text { Benu [benu] 'sabut } \\
\text { kelapa' }\end{array}$ & Base [base] 'basah' & $\begin{array}{l}\text { Benu base [benubase] 'orang yang tidak } \\
\text { dapat diharapkan' }\end{array}$ \\
\hline
\end{tabular}

Pada tabel (1) nomor $1-6$. konstruksi kompositum ini berasal dari kelas kata dasar yang berbeda-beda. Ada konstruksi yang terbentuk dari verba dengan nomina, verba dengan numeralia, nomina dengan nomina, dan nomina dengan numeralia. Pada kompositum idiomatis baliq manuq, makna yang terkandung adalah seorang anak yang pada masa kecilnya biasa saja belum kelihatan aura kecantikan atau ketampanannya. Akan tetapi, pada saat anak tersebut meningkat remaja, ia tumbuh menjadi seorang gadis cantik atau pemuda yang sangat tampan. Sebaliknya, ada kompositum baliq tai yang mengandung makna yang bertolak belakang, yakni pada masa kecil seorang anak kelihatan sangat cantik atau tampan. Namun, pada saat remaja ketampakan anak tersebut menjadi biasa saja atau tidak cantik atau tidak tampan lagi. Selanjutnya, kompositum lembottallu 'ombak tiga' memiliki makna gelombang besar.

Pada kompositum idiomatik mottong manuq, makna yang terkandung ialah apabila seorang tamu yang menginap tidak disuguhi makan malam. Selanjutnya, pada kompositum kayyang pau, dalam bahasa Indonesia berarti sombong, sebagaimana masyarakat Mandar mengiaskan kayyang pau kepada seseorang yang banyak bicara atau banyak bertingkah dengan memamerkan kekayaannya.

Pada kompositum idiomatis lappiq daqdua, makna yang terkandung adalah sesuatu yang berlipat ganda. Masyarakat Mandar biasanya menggunakan idiom ini untuk pedagang yang memperoleh keuntungan yang banyak.

Kompositum berikutnya adalah benu base 'sabut kelapa yang basah'. Sabut kelapa dalam masyarakat Mandar sangat diperlukan terutama untuk keperluan dapur, yakni sebagai bahan bakar. Jadi, apabila sabut tersebut basah tentu tidak dapat dinyalakan atau digunakan. Oleh karena itu, kompositium idiomatis ini mengiaskan seseorang yang tidak bisa diharapkan, tidak bisa apa-apa, atau tidak dapat memberi bantuan apa pun.

Tabel (2)

Kata Berimbuhan+Kata Dasar

\begin{tabular}{|c|c|c|c|}
\hline No & Kata Berimbuhan & Kata Dasar & Kompositum \\
\hline 1. & $\begin{array}{l}\text { Me(l)+lila } \rightarrow \text { mellila } \\
\text { [mel:ila] 'berlidah' }\end{array}$ & $\begin{array}{l}\text { Puarang [puara }] \\
\text { 'biawak' }\end{array}$ & $\begin{array}{l}\text { Mellila puarang [mel:ila puaraๆ] } \\
\text { 'orang yang selalu berbohong } \\
\text { sehingga tidak dapat dipercaya' }\end{array}$ \\
\hline 2. & $\begin{array}{l}\operatorname{Me}(q)+o t a q \rightarrow \text { meqota } \\
\text { [me?ota?] 'berotak' }\end{array}$ & Urang [uraך] 'udang' & $\begin{array}{l}\text { Meqotaq urang [me?ota? ura }] \\
\text { 'berotak udang/-orang yang tidak } \\
\text { menggunakan akalnya' }\end{array}$ \\
\hline
\end{tabular}




\begin{tabular}{|c|c|c|c|}
\hline 3. & $\begin{array}{l}\text { Me(t)+talinga } \rightarrow \text { mettalinga } \\
\text { [met:alina] 'bertelinga' }\end{array}$ & $\begin{array}{l}\text { Jonga [jona] } \\
\text { 'rusa' }\end{array}$ & 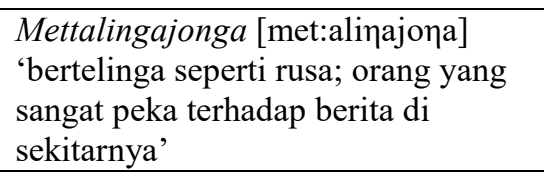 \\
\hline 4. & $\begin{array}{l}\text { Me+anaq } \rightarrow \text { meanaq } \\
\text { [meana?] 'melahirkan' }\end{array}$ & Posa [posa] 'kucing' & $\begin{array}{l}\text { Meanaq posa [meana? posa] 'beranak } \\
\text { seperti kucing; ibu yang sering } \\
\text { melahirkan banyak anak' }\end{array}$ \\
\hline 5. & $\begin{array}{l}\text { Me(s)+sipaq } \rightarrow \text { messipa } \\
\text { [mes:ipa?] 'bersifat' }\end{array}$ & $A s u$ [asu] 'anjing' & $\begin{array}{l}\text { Messipa' asu [mes:ipaq asu] 'bersifat } \\
\text { (seperti) anjing; orang yang } \\
\text { berperangai sangat buruk' }\end{array}$ \\
\hline 6. & $\begin{array}{l}\text { Meq+indoq } \rightarrow \text { meqindo } \\
\text { [mePindo?] 'beribu' }\end{array}$ & $A s u$ [asu] 'anjing' & $\begin{array}{l}\text { Meqindoqasu [mePindo? asu] } \\
\text { 'berinduk anjing: ibu muda yang } \\
\text { dulunya cantik, tetapi setelah } \\
\text { melahirkan menjadi jelek' }\end{array}$ \\
\hline 7. & $\begin{array}{l}\text { Meq }+ \text { ado } \rightarrow \text { meqado } \\
{[\text { mePado] 'mengangguk' }}\end{array}$ & $\begin{array}{l}\text { Bukkur [buk:ur] } \\
\text { 'tekukur' }\end{array}$ & $\begin{array}{l}\text { Meqado bukkur [mePado buk:ur] } \\
\text { 'mengangguk tekukur; orang yang } \\
\text { mudah mengiyakan tetapi susah } \\
\text { membuktikan' }\end{array}$ \\
\hline
\end{tabular}

Pada tabel (2) nomor $1-7$, konstruksi kompositum ini berasal dari satu kelas kata yang sama, yaitu verba berimbuhan pada komponen pertama dan kelas nomina pada komponen kedua. Semua contoh konstruksi kompositum tersebut berasal dari kata berkelas verba dan nomina - sesuatu yang unik karena pada komponen kedua kompositum tersebut mengambil nomina dari nama binatang. Nama-nama binatang tersebut menjadi salah satu komponen yang sangat menentukan dalam muatan makna.

Kompositum mellila puarang mengiaskan seorang yang tidak dapat dipercaya baik karena kebiasaannya yang suka berbohong, maupun karena kebiasaannya yang selalu tidak menepati janji. Pemilihan binatang biawak dalam mewakili sifat manusia seperti itu mungkin disebabkan binatang biawak secara fisik memiliki lidah yang meppekka 'bercabang dua'. Di samping itu, manusia menganggap binatang ini musuh karena binatang ini sering memangsa ternak mereka.

Selanjutnya, muatan makna kompositum idiomatis meqotaq urang 'berotak udang' mengiaskan seseorang yang tidak dapat menggunakan otaknya - tidak bisa berpikir dengan baik. Masyarakat Mandar memilih nama binatang urang untuk mewakili keadaan manusia seperti itu. Hal tersebut dikarenakan otak atau kepala udang itu terletak di belakang tubuhnya.

Muatan makna kompositum idiomatis mettalinga jonga mengiaskan seseorang yang memiliki pendengaran yang peka. Pemilihan nama binatang jonga 'rusa' sangat cocok untuk mewakili sifat manusia yang cepat tanggap mengenai berita aktual di sekitarnya karena pendengaran binatang tersebut memang terkenal sangat sensitif.

Kompositum berikutnya adalah meanaq posa 'beranak seperti kucing'. Kompositum idiomatis ini bermakna seorang ibu yang melahirkan anaknya secara marete (jarak kelahiran anak tidak sampai setahun) sehingga mempunyai anak banyak. Masyarakat Mandar memilih nama binatang posa 'kucing' untuk mewakili keadaan ibu seperti itu. Hal tersebut dikarenakan sifat binatang ini memang beranak banyak.

Kompositum idiomatis yang lain adalah messipa asu 'bersifat anjing'. Kompositum ini memiliki muatan makna yang mengiaskan seseorang yang memiliki sifat buruk dan sangat jahat. Pemilihan nama binatang ini untuk mewakili sifat manusia jahat seperti asu 'anjing'. Anjing dianggap binatang buas 
yang najis dan haram bagi umat Islammasyarakat Mandar umumnya penganut agama Islam yang taat. Selain itu, kompositum yang juga menggunakan nama binatang asu adalah meqindoq asu kompositum ini dikiaskan bagi ibu muda yang sebelum melahirkan kelihatan cantik, tetapi setelah melahirkan kecantikannya itu pudar atau hilang.
Kompositum idiomatik yang terakhir adalah meqado bukkur kompositum ini mengiaskan seseorang yang bersifat sangat gampang mengiyakan sesuatu, padahal sangat susah mewujudkannya. Pemilihan nama binatang bukkur 'tekukur' ini mewakili sifat manusia seperti tekukur yang memiliki sifat yang suka meqado 'mengangguk-angguk'.

Tabel (3)

Kata Dasar+Kata Berimbuhan

\begin{tabular}{|c|c|c|c|}
\hline \multicolumn{4}{|c|}{ 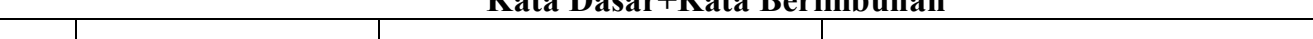 } \\
\hline No & Kata Dasar & Kata Berimbuhan & Kompositum \\
\hline 1. & $\begin{array}{l}\text { Manus } \\
\text { [manus] } \\
\text { 'hanyut' }\end{array}$ & $\begin{array}{l}\mathrm{Si}+\text { parappe } \rightarrow \text { siparappe } \\
\text { [siparappe] } \\
\text { 'saling menaikkan' }\end{array}$ & $\begin{array}{l}\text { Manus siparappe } \\
\text { [manus:iparap:e] } \\
\text { 'hanyut saling menyelamatkan' }\end{array}$ \\
\hline 2. & $\begin{array}{l}\text { Tuppang } \\
\text { [tup:aך] } \\
\text { 'terbalik' }\end{array}$ & $\begin{array}{l}\text { Si+palewa } \rightarrow \text { sipalewa } \\
\text { [sipalewa }\} \text { 'saling angkat' }\end{array}$ & $\begin{array}{l}\text { Tuppang sipalewa } \\
\text { [tup:aךsipalewa] } \\
\text { 'terbalik saling mengangkat' }\end{array}$ \\
\hline 3. & $\begin{array}{l}\text { Malakka } \\
\text { [malak:a] } \\
\text { 'panjang' }\end{array}$ & $\begin{array}{l}P e q+i t a \rightarrow \text { peqita } \\
\text { [pe?ita]'penglihatan' }\end{array}$ & $\begin{array}{l}\text { malakka peqita } \\
\text { [malak:a pe?ita] } \\
\text { 'panjang pandangan/tinjauan' }\end{array}$ \\
\hline 4. & $\begin{array}{l}\text { Masiga } \\
\text { [masiga] } \\
\text { 'cepat' }\end{array}$ & $\begin{array}{l}\text { Pe(l)+liqa } \rightarrow \text { pelliqa } \\
\text { [pel:iPa]'langkah’ }\end{array}$ & $\begin{array}{l}\text { Masiga pelliqa } \\
\text { [masiga pel:i?a] } \\
\text { 'cekatan lincah' }\end{array}$ \\
\hline 5. & $\begin{array}{l}\text { Macoa } \\
\text { [macoa] } \\
\text { 'baik' }\end{array}$ & 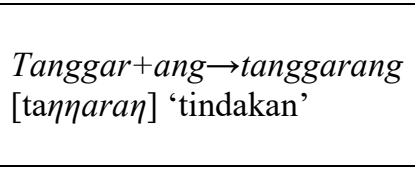 & 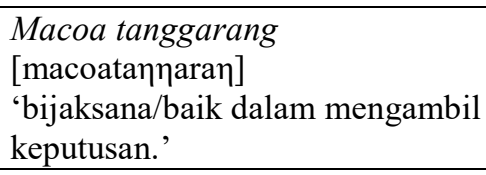 \\
\hline
\end{tabular}

Pada tabel (3) nomor $1-5$, konstruksi kompositum ini berasal dari satu kelas kata yang sama, yaitu kelas adjektiva pada komponen pertama, dan kelas nomina atau verba pada komponen kedua. Kompositum manus siparappe 'hanyut saling menaikkan' memiliki nilai makna pendidikan moral yang sangat tinggi, menjunjung solidaritas di antara sesama. Begitu pula dengan kompositum tuppang sipalewa 'terbalik saling mengangkat', juga memiliki nilai makna pendidikan yaitu saling tolong menolong di antara sesama.

Kompositum malakka peqita memiliki nilai makna pendidikan. Kompositum ini mengiaskan seseorang yang memiliki sifat tegas dan pandangan yang luas dalam mengambil suatu keputusan. Sifat tegas dan padangan luas diperlukan sebagai tinjauan mendalam sehungga mantap dalam mengambil keputusan yang benar, tidak keliru. Begitu pula muatan makna yang terdapat dalam kompositum macoa tangngarang 'baik pandangan', yang bermakna bijaksana dalam mengambil satu keputusan.

Kompositum berikutnya adalah masiga pelliqa 'cepat langkah'. Kompositum ini juga memiliki nilai makna pendidikan. Kompositum ini mengiaskan seseorang yang cekatan dan lincah dalam bekerja. 
Tabel (4)

Kata Ulang+Kata Dasar

\begin{tabular}{|c|c|c|c|}
\hline No & Kata Ulang & Kata Dasar & Kompositum \\
\hline 1. & $\begin{array}{l}\text { Macoa-coa } \\
\text { [macoa-coa] } \\
\text { 'agak bagus' }\end{array}$ & $\begin{array}{l}\text { Uliq } \\
\text { [uli?] } \\
\text { 'kulit' }\end{array}$ & $\begin{array}{l}\text { Macoa-coa uliq } \\
\text { [macoa-coa uliq] } \\
\text { 'kulit kuning langsat' }\end{array}$ \\
\hline 2. & $\begin{array}{l}\text { Sala-sala } \\
\text { [salasala] } \\
\text { 'salah; salah' }\end{array}$ & $\begin{array}{l}\text { Mata } \\
\text { [mata] } \\
\text { 'mata' }\end{array}$ & $\begin{array}{l}\text { Sala-sala mata } \\
\text { [salasalamata] } \\
\text { 'penglihatan kurang jelas' }\end{array}$ \\
\hline 3. & $\begin{array}{c}\text { Malumu-lumu } \\
\text { [malumulumu] } \\
\text { 'agak lembut' }\end{array}$ & $\begin{array}{c}P a u \\
\text { [pau] } \\
\text { 'bicara' }\end{array}$ & $\begin{array}{l}\text { Malumu-lumu pau } \\
\text { [malumulumupau] } \\
\text { 'berbicara lembut' }\end{array}$ \\
\hline 4. & $\begin{array}{l}\text { Loppa-loppa } \\
\text { [lop:a-lop:a] } \\
\text { 'agak panas' }\end{array}$ & $\begin{array}{c}\text { Allo } \\
\text { [al:o] } \\
\text { 'matahari' }\end{array}$ & $\begin{array}{l}\text { Loppa-loppa allo } \\
\text { [lop:a-lop:a al:o] } \\
\text { 'hangat' }\end{array}$ \\
\hline 5. & $\begin{array}{l}\text { Monge-monge } \\
\text { [monemone] } \\
\text { 'agak sakit' }\end{array}$ & $\begin{array}{l}\text { Massengaq } \\
\text { [mas:ena?], } \\
\text { 'mengenang' }\end{array}$ & 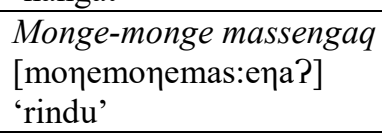 \\
\hline
\end{tabular}

Pada tabel (4) nomor 1-5. konstruksi kompositum ini berasal dari kelas kata yang berbeda. Pada komponen pertama, umumnya, konstruksi berbentuk adjektiva ulang dan pada komponen kedua berasal dari kelas nomina, adjektiva, dan verba. Kompositum idiomatik macoa-coa uliq 'agak baik kulit' mengiaskan seseorang yang memiliki kulit putih atau kuning langsat'. Selanjutnya, kompositum salasala mata mengiaskan seorang yang memiliki penglihatan yang sudah tidak jelas sehingga sering terjadi kesalahan fokus. Kompositum loppa-loppa allo bermakna 'hangat atau suam-suam kuku' dimaknai sebagai sesuatu yang berwujud, misalnya uwai 'air', suhu badan dan sebagainya.

Selanjutnya, makna kompositum malumu-lumu pau dan monge-monge massenga memiliki konstruksi yang sama, yaitu adjektiva berulang pada komponen pertama, dan verba pada komponen kedua. Malumu-lumu pau 'lembut kata/bicara' mengiaskan seorang yang bijak dalam bertutur kata, sedangkan monge-monge massenga 'sakit mengenang' mengiaskan seseorang yang sedang merasakan kerinduan.

Tabel (5)

Kata Dasar+Kata Ulang

\begin{tabular}{|c|c|c|c|}
\hline No & Kata Dasar & Kata Ulang & Kompositum \\
\hline 1. & $\begin{array}{l}\text { Matindo } \\
\text { [matindo] } \\
\text { 'tidur' }\end{array}$ & $\begin{array}{l}\text { Manu-manuq } \\
\text { [manumanu?] } \\
\text { 'burung' }\end{array}$ & $\begin{array}{l}\text { Matindo manu-manuq } \\
\text { [matindomanumanu?] } \\
\text { 'tidur burung;tidur tidak nyenyak' }\end{array}$ \\
\hline 2. & $\begin{array}{l}\text { Tallang } \\
\text { [tal:aך] } \\
\text { 'tenggelam' }\end{array}$ & $\begin{array}{l}\text { Bocing-bocing } \\
\text { [bocimboci ] } \\
\text { 'ubun-ubun' }\end{array}$ & $\begin{array}{l}\text { Tallang bocing-bocing } \\
\text { [tal:ambocimboci }] \\
\text { 'tenggelam sampai ubun-ubun tidak kelihatan' }\end{array}$ \\
\hline 3. & $\begin{array}{c}\text { To } \\
{[\text { to }]} \\
\text { 'orang' }\end{array}$ & $\begin{array}{l}\text { Lebo-leboq } \\
\text { [lebolebo?] } \\
\text { 'lewat-lewat' }\end{array}$ & $\begin{array}{l}\text { To leboleboq } \\
\text { [tolebolebo?] } \\
\text { 'orang baru/ pendatang' }\end{array}$ \\
\hline 4. & $\begin{array}{l}\text { Mangande } \\
\text { [manande ] } \\
\text { 'makan' }\end{array}$ & $\begin{array}{l}\text { Bali-bali } \\
\text { [balibali] } \\
\text { 'dua pihak", }\end{array}$ & $\begin{array}{l}\text { Mangandebali-bali } \\
\text { [manandebalibali] } \\
\text { 'mengambil keuntungan dari dua pihak' }\end{array}$ \\
\hline
\end{tabular}




\begin{tabular}{c|c|c|l}
\hline 5. & $\begin{array}{c}\text { meqate } \\
{[\text { mePate }]} \\
\text { 'berhati' }\end{array}$ & $\begin{array}{c}\text { Baling-baling } \\
\text { [balimbalin] } \\
\text { baling-baling' }\end{array}$ & $\begin{array}{l}\text { Meqate baling-baling } \\
\text { [mePate balimbalin] } \\
\text { 'berhati baling-baling, }\end{array}$ \\
\hline 6. & $\begin{array}{c}\text { Messipaq } \\
\text { [berifat] }\end{array}$ & $\begin{array}{c}\text { Bandera [bandera] } \\
\text { 'bendera' }\end{array}$ & $\begin{array}{l}\text { Messipaq bandera } \\
\text { [mes:ipaPbandera] } \\
\text { 'bersifat seperti bendera' }\end{array}$ \\
\hline
\end{tabular}

Pada tabel (5) nomor 1-6, konstruksi kompositum ini berasal dari satu kelas kata yang sama yaitu verba pada komponen pertama dan kelas nomina berulang pada komponen kedua. Kompositum matindo manu-manuq yang berarti orang yang tidur dalam posisi duduk atau posisi terbaring, tetapi tidurnya tidak lelap.

Selanjutnya, kompositum mangandebali-bali 'makan dari dua sisi' bermakna orang yang mengambil keuntungan dari dua sisi atau dua pihak. Selain itu, juga terdapat kompositum meqate baling-baling makna yang mengiaskan seorang yang memiliki suasana hati yang gelisah dan tidak tenang. Kompositum yang terakhir adalah messipaq bandera 'bersifat seperti bendera' mengiaskan orang yang tidak berpendirian atau selalu berubahubah, seperti bendera yang berkibar.

Beberapa contoh kompositum tersebut merupakan idiom atau ungkapan yang memiliki makna tertentu. Maknamakna khusus tersebut sengaja dibuat atau diciptakan oleh penuturnya untuk memenuhi kebutuhan komunikasi di antara mereka. Beberapa contoh konstruksi kompositum tersebut berasal dari kata yang diambil dari nama binatang. Nama-nama binatang tersebut dipilih menjadi salah satu komponenintensitas pemakaiannya cukup tinggi dalam keseharian penutur bahasa Mandar. Nama beberapa binatang populer seperti manuq, posa, tedong, dan lain-lain dipilih sebagai diksi yang cermat karena binatang-binatang tersebut memiliki persamaan/diperbandingkan dengan sifat, kelakuan, dan keadaan keseharian manusia.
Pemilihan nama binatang pada konstruksi kompositum bahasa Mandar ini pada umumnya diletakkan pada komponen kedua. Kekuatan pengungkapan yang menganalogikan sifat dan kebiasaan binatang dengan sifat dan keadaan manusia mempermudah pemahaman para penutur bahasa tersebut.

Komponen nama binatang dalam kostruksi kompositum ini termasuk kategori nomina bernyawa. Adapun makna yang dikandung adalah makna metafora. Pemakaian kata tersebut bukan dalam arti sebenarnya, melainkan sebagai cerminan yang didasari persamaan atau perbandingan dari kenyataan. Kompositum idiomatis dengan komponen kedua nama binatang menunjukan analogi persamaan bentuk, ukuran, sifat, dan kebiasaan antara binatang dan manusia.

Kompositum idiomatis bagi penutur bahasa Mandar dapat berfungsi sebagai wadah pendidikan dan alat untuk saling mengingatkan di antara mereka. Kompositum idiomatis bahkan dapat menciptakan suasana keakraban, harmonis, sekaligus humoris. Kompositum manus siparappe 'hanyut saling menyelamatkan' sarat dengan nilai makna pendidikan yang mengajarkan solidaritas untuk saling tolong-menolong di antara mereka.

Kompositum idiomatis mellila puarang mengiaskan orang yang suka berbohong, tidak dapat dipercaya. Masyarakat Mandar menganalogikan lidah biawak - yang bercabang dua itusebagai penanda orang yang suka berbohong, meskipun biawak itu tidak tahu berbohong. 


\section{Posisi subjek}

Kompositium idiomatis dapat berposisi sebagai subjek dengan cirinya berupa nomina atau frasa nomina. Kompositum idiomatis sebagai subjek menjadi pokok pikiran dalam kalimat berfungsi untuk menegaskan makna dan membentuk kalimat dasar, kalimat luas, atau kalimat tuggal.

Contoh (1)

1a. Andiangi tuqu macoa mellila puarang 'tidak baik itu berlidah biawak'

(berlidah biawak itu tidak baik).

1b. Lembong tallu maqappaq lopinna anna tallang 'ombak tiga menghantam perahunya sehingga karam' (gelombang besar menghantam perahunya sehingga karam).

\section{Posisi Predikat}

Kompositium idiomatis dapat berposisi sebagai predikat apabila kompositum tersebut berasal dari verba, adjektiva atau frasa verba, dan frasa adjektiva. Kompositum idiomatis sebagai predikat menjadi unsur penjelas pikiran atau gagasan yang diungkapkan oleh agen atau subjek dalam menentukan kejelasan makna kalimat. Predikat juga berfungsi untuk menegaskan makna dan membentuk kalimat.

Contoh (2)

2a. Mettalinga jonga $i$ Kaco 'bertelinga rusa si Kaco' (si Kaco tajam pendengaran).

2b. Meqotaq urangi diqo sanaqekeo 'berotak udang itu anak-anak' (anak itu bodoh).

\section{Posisi Objek}

Kompositium idiomatis dapat berposisi sebagai objek apabila predikat kalimat yang dimasukinya adalah predikat kalimat transitif. Ciri khas objek ini adalah kelas kata nomina dan dapat menduduki fungsi subjek apabila kalimat tersebut dipasifkan. Dalam pembentukan kalimat, objek juga berfungsi untuk menegaskan makna.

\section{Contoh (3)}

3a. I Kaco siala to lebo-leboq 'Kaco menikahi orang pendatang' (Kaco menikahi orang asing/pendatang).

3b. Diqopaqdagango sumaro lappiq daqduai 'itu pedagang untungnya lipat dua' (pedagang itu beruntung lipat ganda).

\section{Posisi Keterangan}

Kompositium idiomatis yang berposisi sebagai keterangan adalah kompositum yang berjenis kata nomina. Jenis keterangan dapat berupa keterangan waktu, tujuan, tempat, syarat, dan posesif. Dalam kalimat, keterangan bukan unsur utama. Jadi, tanpa keterangan kalimat tetap gramatikal.

Contoh (4)

4a. Malolo diqo naibaineo meqareq sindoeroeng 'cantik itu gadis berperut sindoeroeng*' (gadis itu cantik bertubuh langsing).

4b. Masarri-sarri diqe sanaqeke saq tallambukui 'harum ini anak tenggelam tulang-ia' (anak ini menggemaskan karena montok).

Kompositum idiomatis dalam bahasa Mandar banyak terkontruksi dari perpaduan kata dasar dan kata berimbuhan. Salah satu komponen pemadu kompositum yang khas adalah kata dasar nomina yang beraasal dari nama binatang. Diksi nama binatang bermaksud untuk mengungkapkan makna metaforis yang membandingkan kekhasan binatang dengan kebiasaan, keadaan, sikap, dan sebagainya yang terdapat pada diri manusia. 


\section{PENUTUP}

Berdasarkan uraian terdahulu, dapat disimpulkan beberapa hal sebagai berikut.

1) Konstruksi kompositum idiomatis yang ditemukan dalam bahasa Mandar terangkum dalam lima pola kompositum, yaitu pola a) kata dasar+kata dasar, b) kata berimbuhan+kata dasar, c) kata dasar+kata berimbuhan, d) kata ulang+kata dasar, dan e)kata dasar+kata ulang.

2) Konstruksi unik ditemukan dalam pola kata berimbuhan+kata dasar karena komponen kedua konstruksi kompositum tersebut semuanya adalah kelas nomina yang khusus diangkat dari nama binatang. Namanama binatang tersebut dipilih menjadi salah satu komponen pemadu kompositum, dan intensitasnya cukup tinggi dalam keseharian pendukung bahasa Mandar. Nama beberapa binatang populer seperti manuq, posa, urang, tedong, dipilih sebagai diksi yang cermat karena binatang-binatang tersebut mewakili sifat, kelakuan dan keadaan keseharian manusia. Muatan makna kompositum idiomatis bahasa Mandar yang bernilai pendidikan dan solidaritas seperti kompositum manus siparappe. Kompositum idiomatik yang bernilai positif yang berupa pujian seperti kompositum meqareq sindoero-eng, Sebaliknya kompositum idiomatik yang bernilai negatif seperti mellila puarang, dan lain-lain.
Kompositum idiomatis bahasa Mandar dapat menempati posisi subjek, predikat, objek, dan keterangan dalam konstruksi kalimat.

\section{DAFTAR PUSTAKA}

Bloomfield, L. (1933). Language. Henry Holt and Co.

Chaer, A. (2008). Morfologi bahasa Indonesia: Pendekatan proses. Jakarta: Rineka Cipta.

Dabrowska, A. (2018). A Syntactic study of idiom psychological states in English and their constraints. Scholars Publishing.

Grimes, E. C. B. D. G. (1987). Language of South Sulawesi. The Australian Nation University, Department of Linguistics.

Indra, J. (2003). Sistem pemajemukan bahasa Mandar. In D. Sugono (Ed.), Bunga Rampai Hasil Penelitian Bahasa dan Sastra Nomor 4. Balai Bahasa, Pusat Bahasa, Departemen Pendidikan Nasional.

Indra, J. (2019a). Geografi dialek bahasa Mandar di Kabupaten Majene: Suatu kajian singkat. In et. al. Yamaguchi, Masao (Ed.), Penelitian Bahasa Daerah Pulau Sulawesi Terkini (pp. 129-156). Kyoto Publishing Inc.

Indra, J. (2019b). Penanda kompositum dalam bahasa Mandar. Batra, 5(1), 295-303.

Kridalaksana, H. (2013). Kamus Linguistik (IV). Jakarta: PT Gramedia. 
Kandai Vol. 16, No. 2, November 2020; 205-216

Mahsun. (2005). Metodologi penelitian bahasa: Tahapan, strategi, dan metodenya. Depok: PT Raja Grafindo Persada.
Sugono, D. (2008). Bahasa dan peta bahasa Indonesia. Jakarta: Ministry of National Education. 